\title{
On the Artistic Expression of Balzac 's Novel " Pere goriot "
}

\author{
BinQin \\ College of Foreign Languages, Neijiang Normal University, Sichuan, 641112
}

\begin{abstract}
Balzac is a great French writer in the 19th century, and also the founder of realist literary theories. His masterpiece The Human Comedy not only attracted people's wide attention at that time but also occupied a great status in the history of literature nowadays. However, as the opening of The Human Comedy, Le Pere Goriot showed the artistic achievements of Balzac incisively and vividly. Taking the representative work of Le Pere Goriot of Balzac as the discussion object, the great achievements of Balzac are demonstrated through analyzing authenticity of art, means of artistic expression, and language.
\end{abstract}

Keywords: Balzac, Pere goriot, Realism, Artistry

\section{Introduction}

As a great French writer in the 19th century, Balzac is rigorous and keenly observant, with great writing skills. Especially in expression of work artistry, it is miraculous. However, Balzac's work artistry is comprehensive and multiple-aspects, instead of being centralized in a point. Starting from his representative work Le Pere Goriot, the authenticity of art, means of artistic expression, and language are analyzed deeply in this paper, which shows his greatest artistic achievements.

\section{The Artistic Authenticity analysis}

The character of the real, that is, the characters in the novel is only a member of the general public, not the heroes and omnipotent gods. Balzac literature works in the characters, and both are from the real life. Those who have read the "Pere goriot" should be impressed by the "evil flower" of a typical in the capitalist society. He is wise, wise, and speak every word can lead to people's thought; he is fierce, brutal, for money to do the murderous activities; at the same time he is cunning, cautious, in order to drill the law of loom familiar with the code. So how is such a figure, Balzac is how to construct it? In fact, with Balzac's contemporary Jiang Yang thief Viodes is the prototype of the ups and downs of life. The two of them have many internal connections, have repeatedly committed the law, many times jailbreak, and finally have to join the police, when their own enemies. "[2] These in the"The human comedy"we can be confirmed.The existence of the prototype character laid the foundation for the character of the Balzac tectonic vortex, but the devil is a transferee of the author's thought to a greater extent.

Balzac has a very rich life experience, he had a trainee lawyer, many times into the mall, looking for silver, there are many lover, and even participated in the election of members of Congress. He chased money with enthusiasm, but the pursuit of money made him back a huge amount of debt, in the debt had to hide in the process of making him increasingly see the darkness of the capitalist society. The author, through the mouth of the ups and downs, strongly criticized and exposed the essence of capitalist money supremacy, combining art with reality, highlighting the importance of artistic truth, and also as part of its artistic achievement.

Any good literary works, whether in the overall framework of the arrangement or in the details 
of the story has a unique charm, the details of the deal properly, will make the story of the transition and development both in reason but in the expected outside, firmly attracted readers. Balzac in the details of the treatment is very serious and careful, he believes that the details of the real ability to bring the work into a higher literary realmwill make the work sublimation. He said in the first edition of the Children of Heroes and Massimi La Jr: "If people do not follow the copy of the matter, they will not believe them in 1850."Balzac's life is worrying for money, the lack of money on the one hand for the high yield of Balzac works to provide power, on the other hand, Balzac in literary works in particular pay attention to the details of economic details. He described the economic details of the "Pere goriot" with a very precise and realistic picture, such as the old man's home weekend at the table will put tableware to the old man, and respectfully look at this tableware, like respectful Look at the same money. Here, the old man's daughter and son-in-law so respectfully treat a set of utensils, not because of his father's love and respect, but because Pere goriot not been completely drained, the father's property coveted They made such a very funny action. Only through such a small economic details, they vividly expose the bourgeois money-oriented social status quo, showing the family's wealth to the standard as a measure of social reality.

Voltaire had given Rustine had such an account,"If you do not have a patron, you are moldy in the courts of the Mainland, and you can be a half-year-old, if you hold your rice bowl, and you will be married to a queen's daughter, to the six thousand up and down the dowry. Come, thank you. If there is a patron, thirty years old you are the prosecutor, five thousand francs salary, marry the mayor's daughter .... ... you can rise in the age of 40 to do the chief Prosecutors, but also as a member. "[3] These figures are not superfluous, but cleverly through several sets of figures to fully expose the status quo of French society, with real data to speak, so that readers impeccably believe.

Balzac attaches great importance to the description of the environment. "Pere goriot" on the true and meticulous description of the ambush apartment "early Christian grave" appearance and exudes a "occluded, rotten rotting smell" of the interior scene, through a series of corners, such as broken The tile, the dirty ground, the smell of corruption, etc. will be covered as an apartment under the epitome of the lower living environment, show in front of the world, the real nature. Behind and seriously portrayed the son of the son of Bao Sai and Pere goriot two gorgeous style of the mansion, jewels, magnificent description of the high society of the extravagant performance of the most vividly, a huge gap, the reality of social gap is also portrayed vivid. In addition to the material environment, Balzac also profoundly depicts the social environment, which is the specific historical time between people under the social relations. Through the description of the ambush apartment and the three houses and the expression and language of the characters, the complex relationship between the people and the society was vividly on paper.So Balzac skillfully combines the real description of the details with the realistic depiction of the objective environment.

Balzac is the master of the characters and the environment, but also the realist giants, his writing is not fabricated, but with a realistic portrayal of art. Based on the author's understanding, the authenticity of the work itself is particularly important. And Balzac on the description of the environment and the character of such a sense of importance lies in this, first, in order to show the character of the character, such as the cover of the shabby villa reflects the character of the wife, such as the social environment to promote Rustine ambition The formation of the thought of the 
home, etc .; the second is to reproduce the real style of society at that time, rather than his work is a novel, as it is a social history, in this social history, we see the restoration of the dynasty social customs , To understand the people of this era of living environment, see the specific historical stage of the social relations between people characteristics: the decline of nobility, the bourgeoisie, money dominate everything; real description of the social environment based on the premise, the equivalent of an article The soul of the loss of all the real criticism and accusations are pale and weak, less of its historical mission of the support, like a fictional thing will not be long-term people talked about, only the real things will be immortal.

\section{The use of artistic techniques}

Balzac uses a variety of artistic techniques in the text and through the unique character language to complete the shape of the typical characters. Many of the article in the use of exaggeration, Balzac through heavy ink to describe and exaggerate the character of a certain aspect, so that the character more vivid. In the "Pere goriot", he greatly exaggerated the change of his wife's attitude towards the old man. Pere goriot ended the sale in 1813, moved to the Fugai apartment, live in the best of the second floor of the suite, each year from eight to ten thousand francs into the money, Mrs. Fugai affectionately called Pere goriot for Mr. Collio. She thinks the ugly appearance of Pere goriot is decent, and want a variety of ways to fight the idea of Pere goriot. However, a few years later, Pere goriot more and more embarrassed, her attitude is 180 degrees reversal. Balzac through the strong rendering of Mrs. Fugai in the process of courtship love for the flattery of the psychological and was charismatic action, people see her in front of a pile of gold and silver treasure greedy, anxious to take the ugly, through exaggeration, success Shaping a money-like character image, quite ironic. In addition, Pere goriot is also an exaggerated way under the characters, Balzac will be a common love through exaggeration way to add to Pere goriot, so that Pere goriot's father love became infinite distortion and absurdity. No bottom line of love to let him say "I like to pull them for the car, I am willing to do their puppies on the knee," and said in order to let her daughter and others betrayal, you can steal, to grab, to life, and even murder It is hard to imagine that this indescribable exaggeration is so crazy in a bourgeois upstart. In the article Pere goriot spoiled her daughter far more than the pursuit of money, but ultimately the consequences of self. Balzac is through the exaggeration of Pere goriot love, which shows that in the money at the time of the social environment, if the abandonment of the pursuit of money and time and energy are on the valuable feelings, it would be a ridiculous behavior, Will also be a ridiculous emotion, while highlighting the money first on this theme.

There are many contrasts in the "Pere goriot", not only the contrast of the simple environment, such as the contrast between the broken Fugai and moldy "three houses", and the contrast between the characters, such as: Pere goriot two daughters of the old man's attitude before and after the big difference between the contrast and there are two contrast between the layers, such as: aristocratic leader Mrs Bauschon love tragedy. In the restoration of the Bourbon dynasty in France, Mrs. Bauschon was the queen of the social circles of Paris. She had a noble door, an elegant cultivation, a noble respect for the nobility, a cult of the bourgeoisie, and seemed very happy, but with her husband no feelings of political marriage made her longing for pure love. As an aristocratic leader, she understood the rules of "money supremacy" in society, but she was not only drifting in the fashion of money, but also despicable plentiful bourgeoisie, adhere to the traditional lady's ideal. But ultimately, representing her struggle with money society get the love with the Marquis of 
Arazda, but also to the stalemate of the Marquise of Arazda ended. To beat Mrs. Bauschon is not someone else, it is her often the most despicable bourgeoisie Miss, and the reason why she was defeated was not because of the other, because the bourgeoisie had a dowry of two hundred thousand francs per year. Disrespectful Mrs. Bauschon decided to leave the bustling Paris, to the country had a quiet life. In her grand farewell dance, the magnificent scene, bright and beautiful people and Mrs. Bauschon's inner desolation in sharp contrast. We look at Pere goriot and Futaulen, these two are very typical characters. Pere goriot is an obsolete patriarchal person who looks more important than money, and his daughter thinks that money is above all else, and we do not deny the lofty and beautiful parental feelings, but it is so weak in the supremacy of money; Futaulen is the opposite direction of Pere goriot, it is a cruel and cruel guy, and the capitalist creator and exporter are well versed in the way of society, and the irony is the money that makes him again jail. The contrast of these two ideas, profoundly exposed the evil of the capitalist society, whether it is to abandon the money, or the principle of chasing money, and ultimately because of money and behind bars. Balzac through the tragedy love of Mrs. Bauschon, vividly illustrates the decline of the aristocracy and the bourgeoisie in the restoration of the Bourbon period in France, highlighting the inevitable decline of the feudal aristocracy under the irresistible historical trend of the emerging bourgeoisie fate. He faithfully wrote the irreconcilable fate of the aristocracy, but also conveyed sympathy for the decline class, through the use of contrast techniques, shaping the French Bourbon dynasty aristocratic class typical image.

\section{Art language analysis}

Golgi has praised the language arts of Balzac, "Pere goriot" more to its language talent to the limit. The impact of the two life tutors on Rastini is very great, one is the hard servant Futaulen, and the other is the aristocratic leader Mrs. Bauschon. They played an important role in Rastini's step-by-step career, giving Rastini a lot of teaching. But because of the identity of the two status and other aspects of a significant difference, so the same is the understanding of society, they have different expressions. Mrs. Bauschon said: "society is just a group of fools and crooks" "despicable and cruel" "The more you do not have the heart, the higher the rise, you have to be mercilessly against people, people are afraid of you, only men and women as posters, ride them exhausted, to the station to leave; so you can reach the peak of desire", these words seem straightforward but seem very elegant. Futaulen warned Rastini: "The life is the same thing, with the kitchen like the stench. To catch oil and water cannot be afraid of dirty hands, just after the wash: the future of the so-called moral, but that's it", these naked words like claws of steel to put the Rastini's heart into pieces. Thus, Balzac gives different characters to different forms of language, so that the status of characters, personality, age and language style to form a whole, to create a typical, personalized character image.

\section{Conclusion}

In the early 19th century, the critical realism was just started. Balzac stated the issue of authenticity of art specifically through the description of characters, details and environment of Le Pere Goriot, and illustrated the meaning of "art comes from life, but dramatizes life" vividly. Balzac impeccably shaped the typical environment and characters and applied means of artistic expression. Paris, a metropolis with double life melody of both "Paradise" and "Hell on Earth", is 
described vividly in detail with a series of typical characters' depiction, which makes readers comprehend urban "ripples of poetic" fully, namely, money and enjoy. It is of a great artistic research value. The unique and typical shaping and the accurate application of means of artistic expression are the important parts of his artistic achievement. Balzac is both the master who manipulates characters and environment and the giant of realism. His profound and systematic realism proposition opened a new generation of literary and artistic, and created a batch of realistic writers, with the epoch-making significance.

\section{Reference}

[1] Balzac. Human comedy • Preface [M]. Chen Zhanyuan translation. Beijing: People's Literature Publishing House, 1957.3-19

[2] Y.Z. Li. A devil's epic - the image of the volt-cold again [J]. Journal of Jishou University, 1995, (2): 72-76.

[3] Balzac. Pere goriot [M]. Fu Leiyi. Shanghai: YIlin Publishing House, 1993.97,106,262.

[4] Z.R. Zhu. History of Western Literary Theory[M]. Beijing: Peking University Press, 2007.

[5] J.Z. Hu. Western literature and art theory tutorial version second edition (on)[M]. Beijing: Peking University Press, 2003. 